\title{
Modified Agro Waste Rice Husk Ash as Adsorbent for Natural Gas Storage System
}

\author{
Nur Hashimah Alias, Nurul Aimi Ghazali, Tengku Amran Tengku Mohd, Shareena Fairuz Abd Manaf, \\ Nur Azrini Ramlee, and Arina Sauki
}

\begin{abstract}
In this study, the characteristics of methane adsorption using rice husk ash adsorbent (RHA) on structures and physical properties were investigated. The RHA was modified using metal oxides to improve the structural and physical properties as well as to enhance the methane adsorption and desorption performances. Two types of metal oxides were selected which are silver oxide $\left(\mathrm{Ag}_{2} \mathrm{O}\right)$ and magnesium oxide (MgO). The structural properties of modified and unmodified RHA samples were characterized using $X$ - Ray Diffraction (XRD) and Scanning Electron Microscope (SEM) images. Meanwhile, Brunauer, Emmet, Teller (BET) surface area measurement and Thermogravimetric Analyzer (TGA) were used to characterize the physical properties of modified and unmodified RHA samples. The effects of concentrations and type of metal oxides on RHA were investigated. Results showed that metal oxide loading greatly affect the RHA structural and physical characteristics. Meanwhile, SEM results showed that the presence of metal oxide in the surfaces of the RHA results in well - developed porosity. The XRD patterns of metal oxide modified RHA showed the presence of new diffraction peaks, which indicates the attachment of metal oxide in the RHA and the structure of RHA was also maintained after modification. For physical characteristics, the results showed increased in metal oxide concentrations increased the specific surface area of the modified RHA. The TGA results showed that the weight of modified RHA decreased due to the decomposition of hemicellulose and lignin. Finally, the results concluded that the modification of RHA using $\mathrm{Ag}_{2} \mathrm{O}$ have improved the structural and physical characteristics of RHA as an adsorbent. Hence, metal oxide modified RHA can be a promising candidate to enhance the methane adsorption and desorption capacities in a natural gas storage system.
\end{abstract}

Index Terms-Rice husk ash, metal oxide, methane storage, adsorbent, agro waste.

\section{INTRODUCTION}

The adsorption of methane in porous material, in which case gas may be stored (ANG) under moderate pressure (between 507.63 and 508.15 psig) has been studied as alternative for its storage and transport [1]-[4]. The studies have proven that porous carbon possessing large surface area and special porosity features might be the commercially

Manuscript received February 1, 2015; revised December 22, 2015.

Nur Hashimah Alias, Nurul Aimi Ghazali, Tengku Amran Tengku Mohd, and Arina Sauki are with the Department of Oil and Gas Engineering Department, Faculty of Chemical Engineering, UiTM, Malaysia (e-mail: nurhashimahalias@gmail.com).

Shareena Fairuz Abd Manaf is with the Department of Bioprocess Engineering, Faculty of Chemical Engineering, UiTM, Malaysia.

Nur Azrini Ramlee is with the Department of Chemical Engineering, Faculty of Chemical Engineering, UiTM, Malaysia. potential adsorbent [3]. Many researchers reported on adsorption and storage of methane in natural gas in different porous material, including activated carbon (AC), carbon nanotubes and activated carbon fibers $(\mathrm{ACF})$ with different specific surface area and pore sizes [5]. AC is the most adequate material for methane storage system due to its textural properties [6]. AC develops micropore, during activation process due to which oxygen functional group are introduced on carbon surfaces. AC using for natural gas should have arge surface area for high adsorption capacity, favorable pore structure for quick adsorption and desorption procedures, high packing density for high volumetric energy density and good thermal diffusivity for stable temperature during adsorption/desorption process [3].

The abundance and availability of agricultural by-product make them good sources of cheap raw materials for natural adsorbents. For example, AC material prepared from coconut shells using phosphorus acid $\left(\mathrm{H}_{3} \mathrm{PO}_{3}\right)$ chemical activation [7] and rice husk based zeolite [8] has a great potential as methane adsorbent. Rice husk ash is an agricultural waste has been reported as a good adsorbent for methane storage [9], [10]. According to the statistics compiled by the Malaysian Ministry of Agriculture, there are more than 408,000 tonnes of rice husk in Malaysia annually [11]. Converting this material into effective adsorbents can be attractive option to eliminate waste materials [12]. So far, much effort has been made to produce materials that could be adsorb and deliver such amount of methane but little work has reported on inexpensive adsorbent for adsorption to complete successfully on economic ground with alternative separation process. In nature, rice husk is tough, insoluble in water, woody and characterized by its abrasive inherent resistance behavior and silica-cellulose structural arrangement [13]. The chemical compounds of rice husk are found to be silicate tetraoxide $\left(\mathrm{SiO}_{4}\right)$, water $\left(\mathrm{H}_{2} \mathrm{O}\right)$, aluminium oxide $\left(\mathrm{Al}_{2} \mathrm{O}_{3}\right)$, iron oxide $\left(\mathrm{Fe}_{2} \mathrm{O}_{3}\right)$, potassium oxide $\left(\mathrm{K}_{2} \mathrm{O}\right)$, sodium oxide $\left(\mathrm{Na}_{2} \mathrm{O}\right)$, calcium oxide $(\mathrm{CaO})$ and magnesium oxide $(\mathrm{MgO})$ [14]. These compounds varies based on type of paddy sown, proportion of irritated area, geographical condition, fertilizer used, climatic variation, soil chemistry, timeliness of crop production operations and agronomic practices in the paddy growth process [14].

Some of the agro waste rice husk lack of effective thermal transfer with little oxygen $(\mathrm{O})$ and nitrogen $(\mathrm{N})$ functional group on wall. However, the rice husk could be modified through surface treatment to increase the adsorption capacity [15]. The pre - treatment of rice husk increased the cellulose content of the solid fraction by virtue of lignin removal and hemi cellulose solubilisation [10]. Besides that, the 
pre-treatment also caused the cellulose crystallinity to decrease and the porosity of the adsorbent to increase. Hence this present paper discussed on the characterizations of structural and physical properties of agro waste adsorbent from rice husk ash unmodified and modified using metal oxide to improve methane adsorption and desorption capacity

\section{MethodOlOGY}

\section{A. Materials}

The rice husk ash (RHA) was obtained from the local rice mill company, Padiberas Nasional Berhad (BERNAS). The magnesium nitrate, $\mathrm{Mg}\left(\mathrm{NO}_{3}\right)_{2} \cdot 6 \mathrm{H}_{2} \mathrm{O}$ and silver nitrate, $\mathrm{Ag}\left(\mathrm{NO}_{3}\right)$ were used as the metal oxide precursors to modify the RHA. Distilled water was used in the preparation of the modified RHA to minimize the impurities. Metal oxides modifications on RHA were carried out using incipient wetness impregnation (IWI) method.

\section{B. RHA Adsorbent Structural Characterizations}

The crystalline structures studies were carried out using a Siemens D5000 X-Ray Diffractometer (XRD) with $\mathrm{CuK} \alpha$ radiation of $\lambda=1.5418 \AA$ at $40 \mathrm{kV}$ and $20 \mathrm{~mA}$ at scanning speed of $0.05^{\circ}$ per second. In order to assess the structural integrity of the adsorbents before and after modification, the adsorbents were analyzed in a range of $2 \theta=5^{\circ}-50^{\circ}$. Meanwhile, scanning Electron Microscope (SEM) was used in this study in order to characterize the structural feature of the raw and surface modified activated carbon.

\section{RHA Adsorbent Physical Characterizations}

A Micromeritics surface area analyzer (Model No. ASAP 2000) was used to determine the $\mathrm{N}_{2}$ Brunauer, Emmet, and Teller (BET) surface area and pore volume of the unmodified and modified RHA adsorbents. Thermogravimetric analysis was performed using a Perkin Elmer TGA 7, Thermogravimetric analyzer was used to study the thermal stability and dehydration characteristics of the adsorbents.

\section{RESULT AND DISCUSSION}

\section{A. Structural Characterizations}

First structural characterization was carried out using Powder X - Ray Diffraction (XRD) on prepared samples. Fig. 1 compares the XRD patterns of amorphous silica from unmodified RHA and unmodified RHA with thermal treatment at $400{ }^{\circ} \mathrm{C}$ in 2 hours calcination time. The result shows that the structre of unmodified RHA was maintained in amorphous form after the thermal treatment. Broad peak around $2 \theta=22^{\circ}$ diffraction angle were observed in both samples. Fig. 2 shows the XRD pattern of $\mathrm{Ag}_{2} \mathrm{O}$ modified RHA and $\mathrm{MgO}$ modified RHA. The XRD patterns in Ag2O modified RHA indicated three significant peaks at $2 \Theta=$ $38.08^{\circ}, 44.25^{\circ}$ and $64.35^{\circ}$. According to [16], the peaks at $2 \Theta$ $=38.08^{\circ}$ and $64.35^{\circ}$ showed the presence of $\mathrm{Ag}_{2} \mathrm{O}$. Hence, this result concluded that the $\mathrm{Ag}_{2} \mathrm{O}$ was successfully incorporated on the surface of RHA. Meanwhile the XRD pattern for $\mathrm{MgO}$ modified RHA indicated one significant peak at $2 \Theta=62 \cdot 3^{\circ}$. Ref. [17] reported that diffraction angle at this $2 \Theta$ degree value shows the presence of $\mathrm{MgO}$ in the RHA.

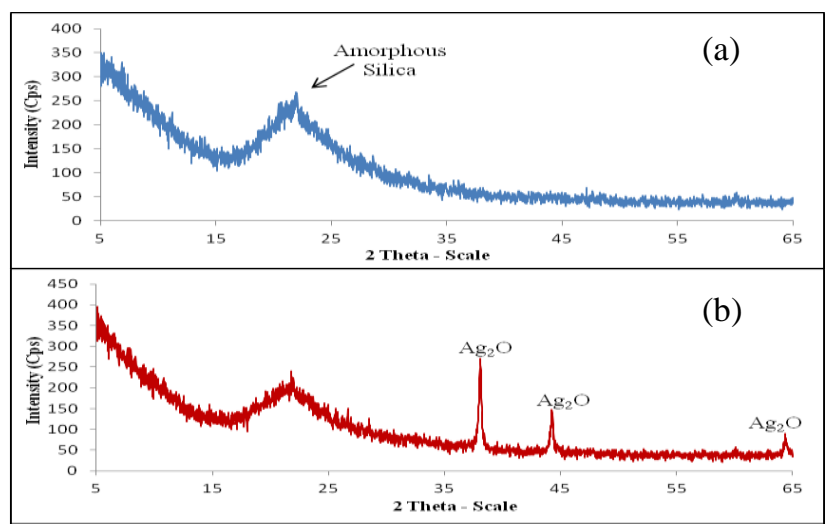

Fig. 1. XRD patterns of: (a) unmodified RHA and (b) unmodified RHA after thermal treatment at $400{ }^{\circ} \mathrm{C}$ and 2 hours.

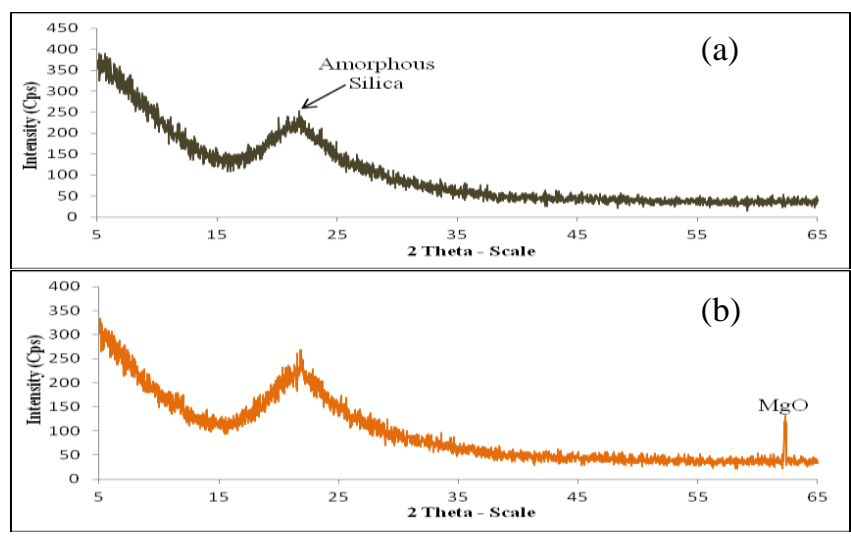

Fig. 2. XRD patterns of: (a) $1 \mathrm{wt} \% \mathrm{Ag}_{2} \mathrm{O}$ modified RHA and (b) $1 \mathrm{wt} \%$ $\mathrm{MgO}$ modified RHA.

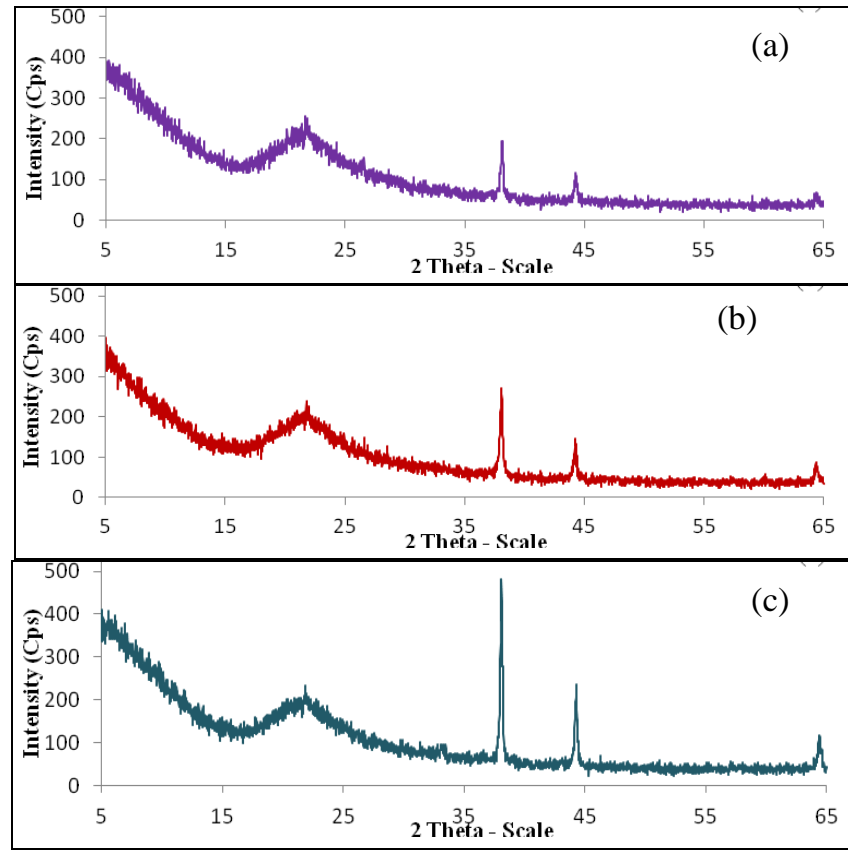

Fig. 3. XRD pattern for $\mathrm{Ag}_{2} \mathrm{O}$ modified RHCA at different loadings after thermal treatment at $400{ }^{\circ} \mathrm{C}$ and 2 hours: (a) $0.5 \mathrm{wt} \%$ : (b) $1 \mathrm{wt} \%$ and (c) 3 wt $\%$ concentrations.

In addition, the peak which indicated that the modified RHA contains amorphous silica at $2 \Theta=22^{\circ}$ was existed in both $\mathrm{Ag}_{2} \mathrm{O}$ modified RHA and $\mathrm{MgO}$ modified RHA structures. These results concluded that the crystallinity structures of 
RHA were preserved after modification. The XRD patterns of RHA modified with $\mathrm{Ag}_{2} \mathrm{O}$ at different concentration ( $0.5 \mathrm{wt} \%$, $1 \mathrm{wt} \%$ and $3 \mathrm{wt} \%$ ) were shown in Fig. 3. These three types of RHA samples were calcined at $400{ }^{\circ} \mathrm{C}$ for two hours before modified with $\mathrm{Ag}_{2} \mathrm{O}$. Based on the result, the diffraction angles for three significant peaks of $\mathrm{Ag}_{2} \mathrm{O}$ modified RHA were present at $2 \Theta=38.08^{\circ}, 2 \Theta=44.25^{\circ}$ and $2 \Theta=64.35^{\circ}$. Thus indicates $\mathrm{Ag}_{2} \mathrm{O}$ was successfully loaded in RHA. Besides that the peak intensities of the $3 \mathrm{wt} \% \mathrm{Ag}_{2} \mathrm{O}$ modified RHA were relatively higher than $1 \mathrm{wt} \%$ and $0.5 \mathrm{wt} \% \mathrm{Ag}_{2} \mathrm{O}$ modified RHA.

Second structural characterization was carried out on the morphological characteristics of unmodified and modified RHA using Zeiss Gemini field emission scanning electron microscope (FESEM). The FESEM photographs of two selected metal oxides modified RHA are shown in Fig. 4. The calcination at $400{ }^{\circ} \mathrm{C}$ produced carbon because at this temperature, hemicelluloses and lignin were decomposed and converted into small particles with large surface area. However, if the temperature is too high (more than $600{ }^{\circ} \mathrm{C}$ ) [18], the RHA will loss the micropore volume due to pore collapsed.

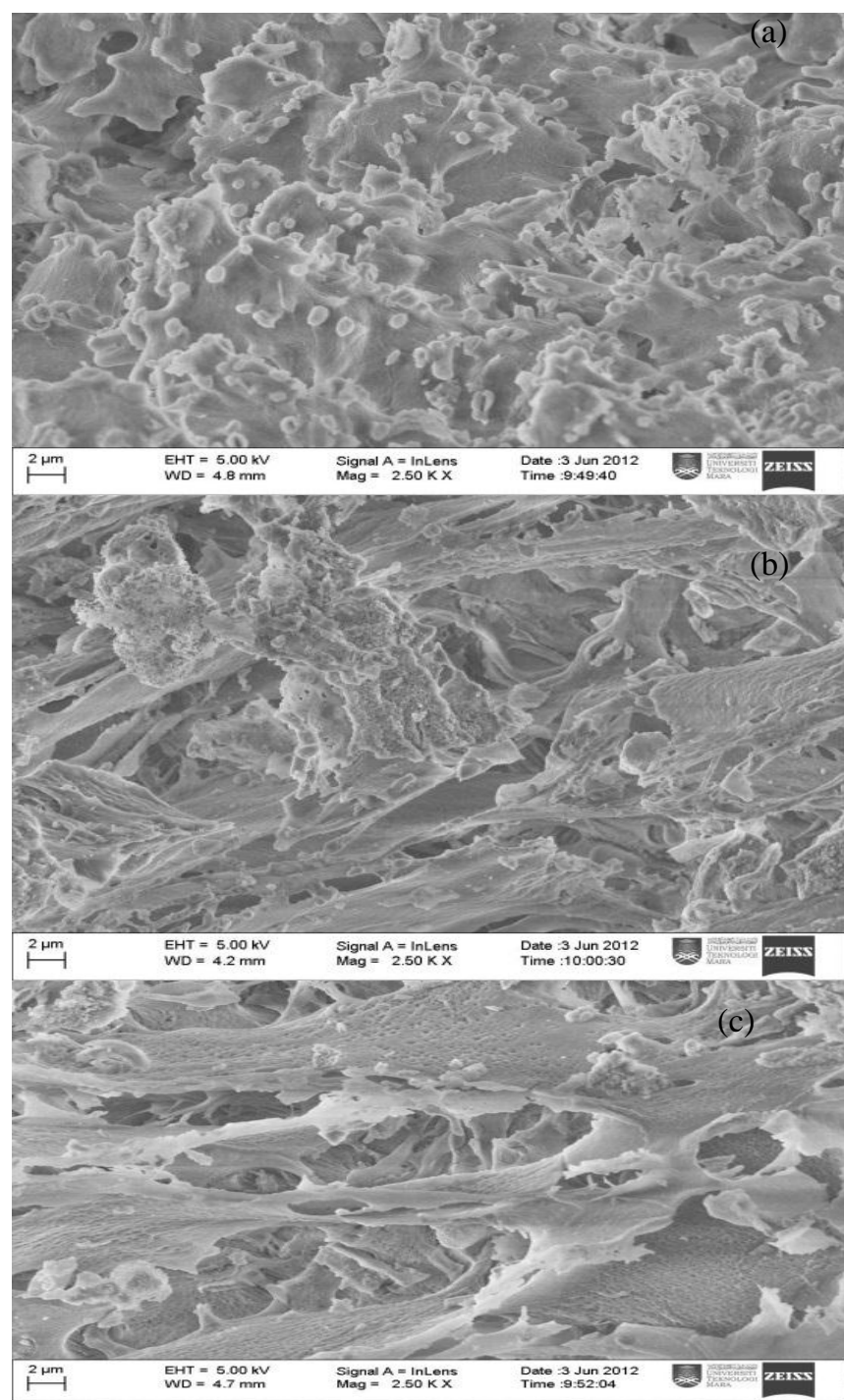

Fig. 4. Cross - sectional FESEM images of (a) unmodified RHA; (b) $\mathrm{Ag}_{2} \mathrm{O}$ modified RHA and (c) MgO modified RHA.

FESEM micrograph of calcined samples showed in unmodified RHA particles, the metal oxides particles disappeared completely in the field of vision. The surfaces of modified RHA look smoother than unmodified RHA. Previous research by [18] also reported that metal oxides surface melting occurred at above Tamann Temperature during $\mathrm{NaY}$ zeolite calcinations even though the calcined temperature is below the metal oxides melting points. Therefore the disappearance of metal oxides particles on RHA was resulted from the formation of thin oxides films on the RHA particles surfaces.

\section{B. Physical Characterizations}

First physical characterization was carried out using Micromeritics surface area analyzer (Model No. ASAP 2000). The loading of metal oxides into RHA easily influences the pore sizes of RHA particles. Physical properties characterization results indicate that BET surface area and pore volume of RHA were increased after calcination and modification using $\mathrm{MgO}$ and $\mathrm{Ag}_{2} \mathrm{O}$ as shown in Table I. The results showed that unmodified RHA with calcination process at $400{ }^{\circ} \mathrm{C}$ for 2 hours increased in surface area and pore volume as compared to unmodified RHA without calcination. This calcination process reduced the content of hemicelluloses and lignin as well as there was a reduction in cellulose crystallinity. At the early stage of thermal treatment, the mass of sample was decreased due to the cellulose decomposition. Then, lignin decomposed for pyrolysis and its char burned for combustion. The maximum decomposition rate of cellulose and lignin was at $350-400{ }^{\circ} \mathrm{C}$ [19]. Besides that, the BET surface area and pore volume of $\mathrm{MgO}$ modified RHA was slightly higher compared to $\mathrm{Ag}_{2} \mathrm{O}$ modified RHA Hence, the modification using metal oxide significantly affects the surface area and pore structure evolution of RHA. This result is in agreement with the results reported by [18].

TABLE I: BET SPECIFIC SURFACE AREA AND PORE VOLUME FOR MODIFIED

\begin{tabular}{|c|c|c|}
\hline Samples & $\begin{array}{c}\text { BET Surface } \\
\text { Area }\left(\mathrm{m}^{2} / \mathrm{g}\right)\end{array}$ & $\begin{array}{l}\text { Pore Volume } \\
\left(\mathrm{cm}^{3} / \mathrm{g}\right)\end{array}$ \\
\hline Unmodified RHA & 12.90 & 2.96 \\
\hline $\begin{array}{l}\text { Unmodified } \begin{array}{l}\text { RHA with } \\
\text { calcinations at } 400^{\circ} \mathrm{C}\end{array} \\
\end{array}$ & 15.50 & 3.56 \\
\hline $1 \mathrm{wt} \% \mathrm{MgO}$ modified RHA & 33.91 & 7.79 \\
\hline $1 \mathrm{wt} \% \mathrm{Ag}_{2} \mathrm{O}$ modified $\mathrm{RHA}$ & 34.36 & 7.92 \\
\hline
\end{tabular}

TABLE II: BET SPECIFIC SURFACE AREA AND PORE VOLUME OF RHA AT DIFFERENT $\mathrm{AG}_{2} \mathrm{O}$ CONCENTRATIONS

\begin{tabular}{|l|c|c|}
\hline \multicolumn{1}{|c|}{ Samples } & $\begin{array}{c}\text { BET Surface } \\
\text { Area }\left(\mathrm{m}^{2} / \mathrm{g}\right)\end{array}$ & $\begin{array}{c}\text { Pore Volume } \\
\left(\mathrm{cm}^{3} / \mathrm{g}\right)\end{array}$ \\
\hline $0.5 \mathrm{wt} \% \mathrm{Ag}_{2} \mathrm{O}$ modified RHA & 30.31 & 6.96 \\
\hline $1 \mathrm{wt} \% \mathrm{Ag}_{2} \mathrm{O}$ modified RHA & 34.46 & 7.92 \\
\hline $3 \mathrm{wt} \% \mathrm{Ag}_{2} \mathrm{O}$ modified RHA & 40.91 & 9.40 \\
\hline
\end{tabular}

Table II shows the result of BET surface area and pore volume when RHA were modified with $\mathrm{Ag}_{2} \mathrm{O}$ at different concentrations $(0.5 \mathrm{wt} \%, 1 \mathrm{wt} \%$ and $3 \mathrm{wt} \%)$. Increased in $\mathrm{Ag}_{2} \mathrm{O}$ concentration increased the surface area and pore volume of modified RHA. This is due to increment of marginally which lead by the formation of complex with the metal oxide. At lower concentration of $\mathrm{Ag}_{2} \mathrm{O}$, the modified RHA are less capable to form a continuous layer on the pore walls to facilitate methane adsorption. [18] previously mentioned that, a large specific surface area is needed to provide more active sites for large adsorption capacity 
besides the pore volume will determines the accessibility and amount of adsorbate molecules that can be adsorbed in the internal RHA surfaces. Thus, higher concentration of $\mathrm{Ag}_{2} \mathrm{O}$ will leads to higher adsorption capacity. However, the increased of metal loading was not continuously increase of the surface area since at certain amount of loaded metal oxide, the surface area decreased due to the pores blockage [20]. This is because, during impregnation into RHA, metal oxide was incorporated at the pore wall. However, further increased of metal oxide loadings will gradually extend the metal oxide pore to mesopore and macropore. Consequently, the pores districted the accessible of adsorbate hence will decrease the adsorption capacity.

Second physical characterization was done using Thermal Gravimetric Analyzer. Fig. 5 shows the Thermal Gravimetric (TG) profile for unmodified RHA, MgO modified RHA and $\mathrm{Ag}_{2} \mathrm{O}$ modified RHA. From Table III it was observed that there are three stages of decomposition that took placed for all samples. Generally, at the first stage of decomposition occurred at a range of $32.33^{\circ} \mathrm{C}$ to $117.35^{\circ} \mathrm{C}$ and this stage the weight losses were attribute to desorption of absorbed moisture. In the second stage of decomposition $\left(66.3^{\circ} \mathrm{C}\right.$ to $\left.393.37^{\circ} \mathrm{C}\right)$, the sample was devolatilisation. The activation was done at this stage. Previous study done by [21], the devolatilisation of rice husk occurred at the temperature of $200-330{ }^{\circ} \mathrm{C}$. At the second stage weight losses occurred due to the three major constituent of cellulose, hemicellulose and lignin in the lignocellulosic material were decomposed. After the second stage, the weight losses for all samples were started to be stabled. In conclusion, unmodified showed higher weight loss $(0.85 \%)$ as compared to $\mathrm{MgO}$ modified RHA $(0.50 \%)$ and $\mathrm{Ag}_{2} \mathrm{O}$ modified RHA $(0.49 \%)$. Overall the TG profile for unmodified and modified RHA illustrated the same patterns but different in range of activation temperatures.

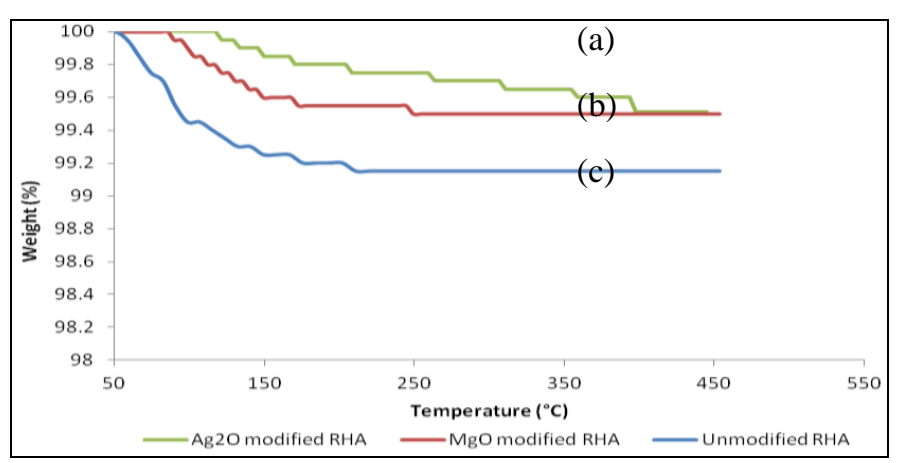

Fig. 5. The TG profile for; (a) Unmodified RHA, (b) MgO modified RHA and (c) $\mathrm{Ag}_{2} \mathrm{O}$ modified RHA.

TABLE III: DECOMPOSITION STAGES FOR UNMODIFIED AND MODIFIED RHA

\begin{tabular}{|c|c|c|c|}
\hline Sample & \multicolumn{3}{|c|}{ Stage of decomposition $\left({ }^{\mathbf{O}} \mathbf{C}\right)$} \\
\hline & 1st stage & 2nd stage & 3rd stage \\
\hline Unmodified RHA & $34.67-117.35$ & $117.35-$ & $393.37-$ \\
& & 393.37 & 445.36 \\
\hline $\mathrm{Ag}_{2} \mathrm{O}$ modified RHA & $34.42-85.34$ & $85.34-$ & $244.3-$ \\
& & 244.3 & 453.42 \\
\hline $\mathrm{MgO}$ modified RHA & $32.33-66.3$ & $66.3-$ & $210.84-$ \\
& & 210.84 & 453.73 \\
\hline
\end{tabular}

\section{CONCLUSION}

Natural gas storage plays a vital role in maintaining the reliability of supply needed to meet the demands of consumers. Rice husk ash is an agricultural waste which can be a potential adsorbent for natural gas storage system. Modification on RHA using metal oxides, $\mathrm{Ag}_{2} \mathrm{O}$ and $\mathrm{MgO}$ greatly showed significant improvement on the structural and physical properties of RHA. Overall, both structural and physical characteristics indicate that metal oxides were successfully impregnated into RHA. The surface modifications of RHA were carried out using incipient witness impregnation method. The result from XRD and SEM shows that $\mathrm{Ag}_{2} \mathrm{O}$ and $\mathrm{MgO}$ improved the structural characteristics of RHA. However, the $3 \mathrm{wt} \% \mathrm{Ag}_{2} \mathrm{O}$ modified RHA sample showed most significant effect of metal oxide modification on RHA where it has higher XRD peak intensities and the surface morphology was smoother as compared to unmodified RHA. In addition, the XRD results proved the presence of $\mathrm{Ag}_{2} \mathrm{O}$ and $\mathrm{MgO}$ peaks in the RHA as well as SEM images which indicate porosity increased as the metal oxides presence in RHA. The physical characterizations using BET and TGA also indicated that the physical characteristics of RHA improved after modification using $\mathrm{Ag}_{2} \mathrm{O}$ and $\mathrm{MgO}$. A 3 wt $\% \mathrm{Ag}_{2} \mathrm{O}$ loading in RHA showed the highest BET surface area $\left(40.91 \mathrm{~m}^{2} / \mathrm{g}\right)$ and highest pore volume $\left(9.40 \mathrm{~g} / \mathrm{cm}^{3}\right)$ as compared to unmodified RHA, $1 \mathrm{wt} \%$ $\mathrm{MgO}$ modified RHA, $0.5 \mathrm{wt} \% \mathrm{Ag}_{2} \mathrm{O}$ modified RHA and 1 wt $\% \mathrm{Ag}_{2} \mathrm{O}$ modified RHA. The TG profiles indicated 3 stages of RHA decompositions and the result showed that $\mathrm{Ag}_{2} \mathrm{O}$ modified RHA possess the lowest weight loss (0.49\%). Generally, modification of RHA with metal oxides generally results in increase the specific surface area and enhances the pore morphology. The gas adsorption marginally increased mainly attributing to the increased in porosity because high adsorption capacity is depend on high affinity sites that can be provided by the adsorbent. In conclusion, $3 \mathrm{wt} \% \mathrm{Ag}_{2} \mathrm{O}$ modified RHA showed the best performance as compared to other samples and it can be a potential candidate as a commercial adsorbent for natural gas storage.

\section{ACKNOWLEDGEMENT}

The authors would like to thank the Ministry of Education (MOE) and Universiti Teknologi MARA (UiTM) for the financial support given through the Research Acculturation Grant Scheme (RAGS), 600-RMI/RAGS 5/3 (78/2013).

\section{REFERENCES}

[1] N. D. Parkyns and D. F. Quinn, "Natural gas adsorbed on carbons," Edward Arnold Ltd. London, pp. 293-325, 1995.

[2] J. Sun, M. Rood, A. M. Rostam, and A. A. Lizzio, "Natural gas storage with activated carbons from a bituminous coal," Gas Separation and Purification J., vol. 10, no. 2, pp. 91-96, 1996.

[3] C. D. Lozano, M. J. Alcaniz, C. L. M. A. De, and S. A. Linares, "Advances in the study of methane storage," Fuel J., vol. 81, pp 1777-1803, 2002.

[4] D. C. S. Azevedo, J. C. S. Araujo, M. Bastos-Neto, A. E. B. Torres, E.F. Jaguqribe, and J. C. L. Cavalcante, "Microporous activated carbon prepared from coconut shells using chemical activation with zinc chloride," Microporous Mesoporous Materials J., vol. 100, pp. 361-364, 2007.

[5] X. R. Zhang and W. C. Wang, "Methane adsorption in single - Walled carbon nanotube arrays by molecular simulation and density functional theory," Fluid Phase Equilibria J., vol 194, pp. 289-295, 2002. 
[6] T. L. Cook, C. Komodromos, D. F. Quinn, S. Ragan, V. C. Menon, and S. Komameni, "Porous adsorbent for vehicle natural gas storage: A review," Porous Material J., vol. 5, pp. 43-58, 1999.

[7] R. B. Rios, F. W. M. Silva, A. E. B. Torres, D. C. S. Azevedo, and J. C. L. Cavalcante, "Adsorption of methane in activated carbon obtained from coconut shell using $\mathrm{H}_{3} \mathrm{PO}_{4}$ chemical activation," Adsorption J., vol. 15, pp. 271-277, 2009 .

[8] K. S. N. Kamarudin, L. M. Wah, C. Y. Yuan, H. Hamdan, and H. Mat, "Rice husk based zeolite as methane adsorbent," Universiti Teknologi Malaysia, Johor, 2004.

[9] U. Kumar and M. Bandyopadhyay, "Sorption of cadmium from aqueous solution using pre-treated rice husk," Biosource Technology J. vol. 97, pp. 104-109, 2006.

[10] W. S. Wan Ngah and M. A. K. M. Hanafiah, "Removal of heavy metal ion from wastewater by chemically modified plant wastes as adsorbent: A review," Biosource Technology J., vol. 99, pp. 3935-3948, 2008.

[11] T. G. Chuah, A. Jumasiah, I. Azni, S. Katayon, and C. S. Y. Thomas, "Rice husk as a potentially low-cost biosorbent for heavy metal and dye removal: A review," Desalination J., vol. 175, pp. 305-316, 2005.

[12] T. H. Liou and S. J. Wu, "Characteristic of microporous /mesoporous carbon prepared from rice husk under base and acid treated condition: A review," Hazard Materials J., vol. 171, pp. 693-703, 2009.

[13] A. A. M. Daifullah, B. S. Girgis, and H. M. H. Gad, "Utilization of agro residues (rice husk) in small waste water treatment plants," Meterial Letters J., vol. 57, p. 1723, 2003.

[14] Q. Feng, F. Lin, F. Gong, S. Sugita, and M. Shoya, "Adsorption by rice husk ash of lead and mercury: a review," Colloid and Interface Science J., vol. 274, pp. 1-8, 2004.

[15] E. I. El-Shafey, "Sorption of $\mathrm{Cd}(\mathrm{II})$ ans $\mathrm{Se}(\mathrm{IV})$ from aqueous solution using modified rice husk: a review," Hazard Materials J., vol. 147, pp. $546-555,2007$

[16] N. Ravichandraraju, "Studies on the photo-activation of silver-oxide thin films prepared by pulsed laser deposition," Indian Institute of Technology Madras, PhD Thesis, 2011.

[17] C. E. J. Dancer, F. L. Cullen, R. I. Todd, and C. R. M. Grovenor, "How can we quantify magnesium diboride using X-Ray Diffraction," University of Oxford, PhD Thesis, 2005.

[18] Y. Y. Cheing, "A study on structural and gas adsorptive characteristics of metal oxides modified zeolite adsorbents," Univeristi Teknologi Malaysia, Master Thesis, Unpublished, 2006.

[19] A. Gani and I. Naruse, "Effect of cellulose and lignin content on pyrolysis an combustion characteristic for several types of biomass," Renewable Energy J., vol. 32, pp. 649-661. 2007.

[20] K. S. N. Kamarudin and N. Alias, "Adsorption performance of MCM-41 impregnated with amine for $\mathrm{CO}_{2}$ removal," Fuel Processing Technology J., vol. 106, pp. 332-337, 2013.

[21] K. G. Mansaray and A. E. Ghaly, "Agglomeration characteristic of alumina sand - Rice husk ash mixture at elevated temperatures," Energy Sources J., vol. 19, pp. 1005-1025, 1997.

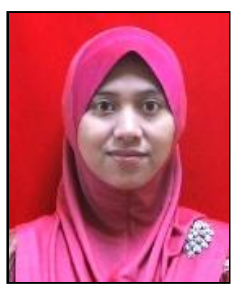

Nur Hashimah Alias received her bachelor of chemical-gas engineering degree from the Universiti Teknologi Malaysia (UTM) in 2007. Subsequently, in February 2012, she received her master degree from UTM in Gas Engineering with financial scholarship from Young Lecturer Scheme Universiti Teknologi MARA (UiTM). Now, she is a lecturer in the Department of Oil and Gas Engineering, Faculty of Chemical Engineering, UiTM since 2011. Nur Hashimah also manages to secure several local research grants and publishing papers in oil and gas engineering related areas.

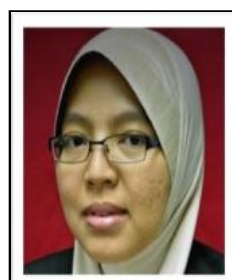

Nurul Aimi Ghazakli received her bachelor of chemical engineering degree from the Universiti Teknologi MARA (UiTM) in 2007. Nurul Aimi was a processs engineer in ALCIM (M) Sdn Bhd for 2 years. In August 2011, she received her master degree from University of New South Wales (UNSW) in Petroleum Engineering with financial scholarship from Young Lecturer Scheme UiTM. Now, she is a lecturer in the Department of Oil And Gas Engineering, Faculty Chemical Engineering, UiTM since 2011. Nurul Aimi also manages to secure a few local research grants and publishing several papers specifically in drilling fluids formulation.

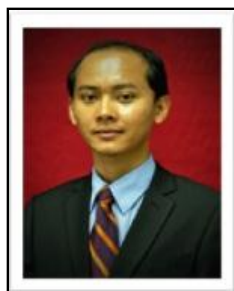

Tengku Amran Tengku Mohd received his bachelor of chemical engineering degree from the Universiti Kebangsaan Malaysia (UKM) in 2007. Subsequently, in 2010, he received his master degree from Universiti Teknologi Petronas (UTP) in petroleum engineering with financial scholarship from Young Lecturer Scheme UiTM. Now, he is a lecturer in Department of Oil and Gas Engineering, Faculty of Chemical Engineering, UiTM since 2010 Tengku Amran also manages to secure a few local research grants and publishing several papers in oil and gas engineering related areas. His research interests are in reservoir engineering and enhanced oil recovery.

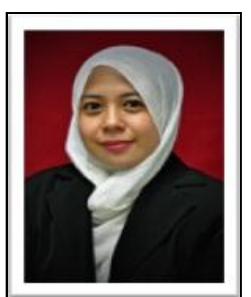

Shareena Fairuz Abd Manaf received her bachelor of chemical engineering degree from the International Islamic Universiti Malaysia (IIUM) in 2008. In 2010, she received her master degree from Universiti Kebangsaan Malaysia (UKM) in chemical engineering and process. Now, she is a lecturer in the Department of Bioprocess Engineering, Faculty of Chemical Engineering, UiTM since 2011. Shareena also manages to secure local research grants and publishing several papers in bioprocess engineering related areas. Her research interests are in biomaterial and bioprocess engineering.

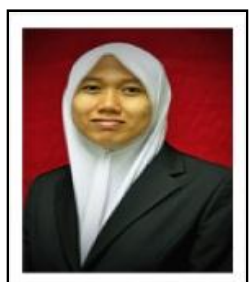

Nur Azrini Ramlee received her bachelor of chemical engineering degree from the Universiti Teknologi Malaysia (UTM) in 2007. In February 2009 , she received her master degree from UTM in chemical engineering. Nur Azrini was a researcher in Malaysia Institute of Nuclear Techology for 3 years. Now, she is a lecturer in the Department of Chemical Engineering, Faculty of Chemical Engineering, UiTM since 2011. Nur Azrini also manages to secure several local research grants and publishing papers in material engineering related areas. Her research interest sare in composite material and membrane separation.

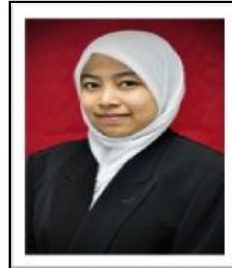

Arina Sauki received her bachelor of chemical engineering degree from the Universiti Teknologi MARA (UiTM) in 2008. In 2012, she received her master degree from Universiti Teknologi Petroleum (UTP) in Petroleum Engineering with financial scholarship from Young Lecturer Scheme UiTM. Now, she is a lecturer in Department of Oil and Gas Engineering, Faculty of Chemical Engineering, UiTM since 2011. Arina also manages to secure local research grants and publishing several papers in oil and gas engineering related areas. Her research interests are in drilling fluid formulation and cementing. 